\title{
POWER REQUIREMENT FOR SOWING PATTERNS ON TWO FALLOW LANDS UNDER WHEAT PRODUCTION
}

\author{
KHURSHID, F. F. ${ }^{1}-$ SEDEEQ, A. M. A. ${ }^{2 *}$ \\ ${ }^{1}$ College of Agricultural Sciences, University of Sulaimani, Sulaimani, Iraq \\ (e-mail: fawzy.khurshid@univsul.edu.iq; phone: +964-770-144-2400) \\ ${ }^{2}$ College of Agriculture and Forestry, University of Mosul, Mosul, Iraq \\ *Corresponding author \\ e-mail: arkanma.agri.col@uomosul.edu.iq; phone: +964-770-162-2813
}

(Received 22 ${ }^{\text {nd }}$ Apr 2019; accepted 20 ${ }^{\text {th }}$ Aug 2019)

\begin{abstract}
An experiment related to wheat cultivation was conducted at south of Sulaimani province, Kurdistan region- Iraq during autumn in 2016-2017. Completely Randomized Block Design was applied with split-split plot arrangement, and the experiment was conducted on two fallow lands, the first land was plowed in the spring and the other remained unplowed, two different sowing modes with rotary seed broadcaster were used, namely conventional and overlapped prose lines, and two similar sets of tillage systems were chosen for the study. The averages were compared by using Duncan's test. The coefficients of variance $(\mathrm{CV})$ for overlapped and conventional seed spreading were $9.2 \%$ and $48.4 \%$, respectively. The spring-plowed fallow land proved to obtain significantly different values compared to the unplowed land, which were higher by $51.9 \%, 48.5 \%, 47.1 \%, 26.9 \%, 31.6 \%, 6.7 \%$ and $30.1 \%$ for fuel consumption, draft, power losses due to slippage, working time, energy utilization, wheat yield and total cost, respectively. The average results for overlapped seed broadcasting were higher than those of the conventional manner by: $0.8 \%, 0.3 \% 1 \%, 0 \%, 3.3 \%, 6.7 \%$ and $14.5 \%$. The lowest values were resulted from applying: $\mathrm{MB}$ plus seed distributor plus $\mathrm{MB}$, while, the maximum yield was given by applying: cultivator plus seed distributor plus cultivator.
\end{abstract}

Keywords: land type, fuel consumption, cultivator, spreading modes

\section{Introduction}

Cereal crops are considered to have a fundamental importance in human life. They have had an essential role in the past. Cereal crops are the mainstay of food supply and the development of the world's people at all times. In Kurdistan region- Iraq, the availability of suitable agricultural land, labour, abundance of water and adequate climate for the cultivation of many of the strategic crops are regarded as the ingredients of successful agricultural operations. Wheat and barley are special crops which help to strengthen and install the status of the agricultural sector in a stable level position to provide a durable and robust economy of the region.

The total arable land area in Kurdistan region- Iraq, was 968468.48 ha, 664771.5 ha of wheat farms that produce 1019481 tons, and constituted $34 \%$ of Sulaymani area. Sowing patterns employed by farmers vary considerably from area to area. The vast majority of the farmers spread their seeds by broadcaster machines after preparing the field in different ways to avoid costs. In addition to fallow rotation few farmers who owned large farms drilled their seeds. Of course, production is noteworthy various in quantity and quality.

The main objective of tillage is to prepare the soil or the seedbed where the plants can easily grow. The crop rotation system, which consists of wheat-fallow, is widely applied in the Kurdistan Region, as is the case in other places in semi-dense and dry 
areas, even in some rain-fed areas. Aims of fallow are to maximize soil water storage through improved water capacity, reduce evaporation; maximize plant nutrient availability; and minimize soil erosion risk (Greb, 1979).

Zengin and Ocakoglu (2013) found that the plowing (stubble fallow method) was more effective than the other methods in terms of high grain yield and yield components. Yield increase of $\sim 50 \%$ was observed in both years when compared to the minimum tillage (stubble fallow method) when they studied the effect of different tillage patterns and fallow methods (minimum tillage/stubble fallow, plowing/stubble fallow and plowing/non-stubble Fallow) on wheat yield, and yield components.

Tillage methods have different tillage depths and ability to change soil physical and chemical properties that affect the crop yield and quality (Strudley et al., 2008). Farmers have begun to apply reduced and no-tillage management practices for production of grain in their fallow lands instead of conventional tillage systems. The main reasons for this idea of less tillage are reduced fuel and labour costs, lowered soil erosion, and enhanced water conservation. The growth in soil water decreases some of the hazard in semiarid and arid farming lands (Broder et al., 1984). Even though overall national yield data of wheat crop mention that it is increasing slowly. However, feasibility is declining due to soil fertility decline, weed problem, disease and insects, labour and power scarcity, and the high cost of inputs (Asheesh et al., 2017).

In general, wheat production in large areas will depend upon mechanized production systems efficiently used and managed. Special attention should be given during the selection of the appropriate machine for proper land preparation and suitable sowing methods for high and profitable crop yield (Mergani, 2006). Askari and Khalifahamzehghasem (2013), pointed out that the needed force to pull the Moldboard plow $(16.30 \mathrm{kN})$ is about five times larger than the needed force of field cultivator (3.49 $\mathrm{kN}$ ), which correlates with the data estimation that obtained from ASABE, 2016, that is $19.55 \mathrm{kN}$ and $3.82 \mathrm{kN}$ respectively.

Botta et al. (2006) and Kahloon et al. (2012) reported that, the maximum economic benefit of the farmers reduced when fuel consumption increased, so that tillage equipment was used in cultivating of wheat. As a principle, in general it can be said that one pass for planting compared to two or extra tillage implementations means fewer hours on a tractor operation, fewer labour hours to pay and may reduce production costs or more acres to farm. Çarman et al. (2013) mentioned that, currently, the search for alternative economic methods for tillage is an inevitable consequence of the high cost of energy spent on conventional tillage, on the other hand, conservation tillage means any plowing or planting method that leaves crop residues covering the field by at least $30 \%$ after seeding practice. Erosion in such soils is reduced by at least $50 \%$ compared to the fallow soil.

Hanna (2016) showed that the highest value of effective field capacity (A/hr) was recorded by the fertilizer spreader compared to other machines which were 4.1, 6.8, 14.4, 5.1 and 20.4 for Moaldboard plow, Chisel Plow, Field cultivator, Grain drill and Fertilizer spreader respectively. Mckyes (1985) defined energy efficiency as the number of cubic meters of soil raised by plows for each megajoule of consumed energy. This efficiency is affected by several factors, the most important of which is the depth of tillage. Muhsin (2017) mentioned that the energy utilization efficiency and the plowed soil volume rate increased by $34.30 \%$ and $87.38 \%$ when the plowing depth increased from 10 to $30 \mathrm{~cm}$, respectively. 
Bai et al. (2008) recommended that the absence of suitable machinery and the trepidation of a reduction of yield make it difficult for farmers to adopt an attitude towards the idea of reducing traffic. By minimizing the machines traffic, the bulk density in the $0-0.15 \mathrm{~m}$ of the soil layer was reduced, the total porosity in the $0-0.60 \mathrm{~m}$ soil layer was increased, better available water content and best saturated hydraulic conductivity were characteristic compared with the traditional mouldboard tillage treatment

In early American history, wheat was sown broadcast. Broadcasting has been observed to reduce plant establishment as seeds are said to be lost to pests and unsuitable weather conditions. Thus, high seed rates have been recommended when seeds are broadcast in order to compensate for seed loss. Presently in America almost all wheat is drilled. The main reason given for drilling wheat was better germination, which resulted in higher stands compared to broadcasting. Though favored crop incorporation and crop yield have been reported when wheat is planted by seed drill compared to other sowing patterns, however, wheat drilling is a costly technology regarding labor requirements for drilling or machinery employed in seed drilling. Thus, seed broadcasting is common in farmers' plots. It was observed, seed broadcasting even when followed by harrowing or raking does not bring seed in ideal contact with the soil for sufficient water uptake (Oyewole et al., 2001).

Broadcasting is the process of random spreading of seed on the surface of seedbeds at controlled rates. Hassann et al. (2009) studied the effect of different field plot area on wheat planting machinery performance. The results showed that it is important to notice that seed drill planter allowed a saving in wheat seeds of $26 \%$ compared with the seed spreader. Wuest et al. (1999) showed that, distinct technique of seeding and seed-soil contact had strong influence time to germination. Lan et al. (1999) confirmed that uniformity for seed spaces is important for crops because it has an influential role in crop production. There are a lot of environmental and economic reasons for using more accurate broadcasters as a device of reducing undesirable environmental effects (Sanaeifar and Sheihkdavoodi, 2012). The relevance of soil and its physiological effects on plants had not been specified perfectly yet, but it was estimated that unfavorable effects of non-uniformity of broadcasting would economically lose a considerable amount of money (Svensson, 1990). The basic performance parameter of a broadcaster is uniformity of spreading over a wide range of situations, this parameter determines the quality of broadcasting, if the broadcasting is suitable the quality will improve better (Speelman, 1979). To help avoid unregularly stands, the equipment should be driven close enough to overlap the previous spread pass to guarantee regular seed distribution (Zewdu, 2008).

All seed broadcaster operators in the region follow the conventional method to spread Wheat granules. The traditional method means spreading granules without overlapping broadcast applications, even the operators leave untreated areas, or sometimes the overlapping of the broadcasting curve may be within a distance not exceeding $2 \mathrm{~m}$, the reason is the operator use visual oversight to the tractor wheel traces, also he often depends on his guessing and skill to achieve parallel swaths in the field. All this results in a heterogeneous distribution of seeds over the field surface. Of course, the production become uneven in quantity and quality from place to place in the field.

Even after all spreader adjustments obtainable have been tested, the distribution shape from a broadcaster is not adequately uniform. A common recommendation in many books and technical papers was mentioned to solve the problem of non- 
uniformity of the granular by making rate of application for half and cover the field twice at perpendicular angles (Colvin and Turner, 1980). But, also this technique is not the best manner to solve this problem (Parish, 1999). Effective overlap (30 to 50\%) between adjacent passes is absolutely necessary to overcome this uneven distribution shape (UMass Extension, 2011).

Broadcasting not only requires higher seed rate but also results in lower plant population, whereas drill sowing method is recommended because of its uniform seed distribution and sowing at the desired depth, which usually results in higher germination and uniform stand. A key factor in the highest wheat production is the understanding of early crop establishment. Beside other agronomic factors seed rate and sowing method are major factors which determine the crop vigour and ultimate yield (Soomro et al., 2009)

It is known that the conventional mode for wheat sowing by seed spreader lead to distribute the wheat grains in a heterogeneous shape that leave places on the soil surface without seeds or light coverage, while other areas are covered with grain intensively which increases the competition between plants to obtain the necessary energy sources for appropriate growth, in addition the negative effects of irregular distribution of seeds results in the loss of a lot of money (Svensson, 1990). Therefore, the variation in the distribution of seeds on the soil surface and uneven emergence, depth and stands often result in lower production (Herbek and Lee, 2009). On the other hand, following the overlapping pattern for scattered lines by seed broadcaster is the best solution to the disadvantages of the uneven seed distribution that mentioned by Zewdu (2008).

It can be said, most farmers tend to raise their seeding rates when they used spinning disc type broadcaster. Higher seeding rates normally only lead to more seed costs and produce excessive plant populations. While bad stands as a result of poor seeding rate that prosed by broadcaster typically result in variation in soil-seed contact, seed scattered and seeding depth, predation of seed on the soil surface by birds, insects and mice in addition to high dense weed population that compete for available moisture (Brennan and Leap, 2014; Houk, 2009).

An effective technique to ensure improvement of the uniformity is to cut both the application rate and the swath width to half while preserving parallel swaths (Parish, 1986). For further explanation of half-width method, spread curve overlap of $100 \%$ is commonly needed to obtain uniform coverage. That mean, if the spread pattern width is $10 \mathrm{~m}$ wide, then a $100 \%$ overlap will result in a 5-m swath spacing width.

Generally, most farmers sowed own wheat by spinning disc type seed spreader by conventional mode after preparing the soil by variance tillage systems, which varies from place to another in the region, in terms of the type of machines used and the number of mechanical operations in order to get a quick profit through reducing time, effort and spent money, without taking into account the recommendations and the basis of the management of agricultural operations when using the machines with the right method. Here, the objective of this study was extracted.

The objective of this study is to evaluate the economic feasibility and relative profitability of various combinations of two sowing patterns for wheat crop in two different prepared fallow lands after introducing the advanced technique (overlapping manner) for wheat sowing by granules broadcaster machine at acceptable cost and energy consumption and comparing the results with those in conventional manner in order to improve wheat production through increasing the productivity per unit area. 


\section{Materials and methods}

This study was carried out under rainfed conditions during the growing seasons at Experimental Farms of the College of Agricultural Sciences, University of Sulaimani at Bakrajo located in the southwest of Sulaimani province, Kurdistan region- Iraq (Latitude: $35^{\circ} 33^{\prime} \mathrm{N}$; Longitude $45^{\circ} 27^{\prime} \mathrm{E}$ at an altitude of approximately $830 \mathrm{~m}$ ). In this region, the climate is rainy and cloudy in winters, rainy in springs, hot and dry in summers, the information on agro-climatic conditions is given in Table 1. The physical properties of the soil of the experimental field were examined in the Soil and Water Department laboratories at the College of Agricultural Sciences Table 2.

Table 1. Agro-climatic conditions at the Bakrajo Experimental Station for three cultivation seasons

\begin{tabular}{|c|c|c|c|c|c|c|c|c|c|c|c|}
\hline \multirow[t]{3}{*}{ Season } & & \multirow[b]{2}{*}{ Oct. } & \multirow[b]{2}{*}{ Nov. } & \multicolumn{5}{|c|}{ Months } & \multirow[b]{2}{*}{ May } & \multirow[b]{2}{*}{ Jun. } & \multirow{2}{*}{ Total } \\
\hline & & & & Dec. & Jan. & Feb. & Mar. & Apr. & & & \\
\hline & & & & \multicolumn{5}{|c|}{ Precipitation $(\mathrm{mm})$} & & & \\
\hline $2014-2015$ & & 43.2 & 151.6 & 128.6 & 100.0 & 65.0 & 98.4 & 25.8 & 19.8 & 0.0 & 632.3 \\
\hline $2014-2016$ & & 114.2 & 197.2 & 75.8 & 110.6 & 76.2 & 171.8 & 57.6 & 12.2 & 0.0 & 830.8 \\
\hline \multirow[t]{2}{*}{ 2016-2017 } & & 13.7 & 44.5 & 149.4 & 59.2 & 96.5 & 111.5 & 54.5 & 20.0 & 0.0 & 566.7 \\
\hline & & & \multicolumn{6}{|c|}{ Air temperature $\left({ }^{\circ} \mathbf{C}\right)$} & & & \\
\hline \multirow{2}{*}{ 2014-2015 } & Max. & 35.3 & 13.9 & 12.6 & 16.9 & 20.1 & 23.0 & 33.2 & 37.6 & 34.2 & \\
\hline & Min. & 9.2 & 6.9 & 2.5 & -2.5 & 0.5 & 3.4 & 5.4 & 11.4 & 14.6 & \\
\hline \multirow{2}{*}{ 2015-2016 } & Max. & 34.4 & 13.3 & 12.1 & 16.6 & 19.8 & 22.0 & 32.2 & 36.9 & 34.1 & \\
\hline & Min. & 9.1 & 6.1 & 2.2 & -3.2 & 0.2 & 3.2 & 5.0 & 11.2 & 15.4 & \\
\hline \multirow{2}{*}{ 2016-2017 } & Max. & 32.7 & 24.3 & 18.0 & 15.8 & 30.1 & 24.8 & 32.4 & 39.2 & 37.6 & \\
\hline & Min. & 8.7 & 8.0 & -2.9 & 1.8 & -2.5 & 1.2 & 2.8 & 14.4 & 15.4 & \\
\hline
\end{tabular}

Table 2. Soil physical properties of the experimental area to depth $(20 \mathrm{~cm})$

\begin{tabular}{c|c|c|c|c|c|c|c|c}
\hline $\begin{array}{c}\text { Sand } \\
\left(\mathbf{g . k g}^{-1}\right)\end{array}$ & $\begin{array}{c}\text { Silt } \\
\left(\mathbf{g . k g}^{-1}\right)\end{array}$ & $\begin{array}{c}\text { Clay } \\
\left(\mathbf{g . k g}^{-1}\right)\end{array}$ & $\begin{array}{c}\text { Texture } \\
(\mathbf{P . S . D})\end{array}$ & PH & $\begin{array}{c}\text { S.W.C } \\
(\boldsymbol{\%})\end{array}$ & $\begin{array}{c}\mathbf{O}) \mathbf{M} \\
\left(\mathbf{g . k g}^{-1}\right)\end{array}$ & $\begin{array}{c}\text { Bulk density } \\
\left(\mathbf{g} / \mathbf{c m}^{\mathbf{3}}\right)\end{array}$ & $\begin{array}{c}\text { Penetration } \\
(\mathbf{K p a})\end{array}$ \\
\hline 48.5 & 449.8 & 501.7 & Silty clay & 7.44 & 16 & 21.02 & 1.32 & 1370.5 \\
\hline
\end{tabular}

\section{Field experiment}

For wheat cultivation, the year fallow system is one of the most common manners followed by growers as crop rotation in Iraqi-Kurdistan's large rain fed region. Therefore, two fallow lands were selected for conducting current research, the first fallow land as (F1) was plowed one time at the spring of 2016 at a depth of $0.25 \mathrm{~m}$, while the second fallow land as (F2), was left in a resting stage without conducting any mechanical operation until the time of research. Adopting the overlapping ratios of $30 \%$ to $50 \%$ for prose lines of seed spreader was necessary to achieve acceptable values of the coefficient of variance (C.V.) (be as close to zero as possible). Values up to $15 \%$ are acceptable, but once the CV goes above $20 \%$ a crop and financial loss will happen (Forristal and Teagasc, 2017). 
Two sets of sowing patterns were selected for the current experiment, the sowing of wheat seeds was applied by following the conventional mode of seed scattering and the intertwined mode of prose lines. Each set was consisting of the following patterns:

1. Soil tillage by moldboard plow one pass plus sowing with seed broadcaster and covering the seeds by moldboard plow one pass as (T1).

2. Soil tillage by moldboard plow one pass plus sowing with seed broadcaster plus covering the seeds by field cultivator one pass as (T2).

3. Soil tillage by field cultivator one pass plus sowing with seed broadcaster plus covering the seeds by field cultivator one pass as (T3).

4. Sowing with seed broadcaster plus covering the seeds by moldboard plow one pass as (T4).

5. Sowing with seed broadcaster plus covering the seeds by cultivator one pass as (T5).

Therefore, the number of sowing patterns becomes ten, five of them conducted by conventional sowing mode (farmers practice) and five patterns applied by adopting the overlapping mode of seed prose lines, as illustrated in Table 3. The experiment was carried out in a randomized plot design with a split-split plot arrangement by placing the condition of the fallow lands (F1 and F2) in the main plots, the sowing modes (conventional and overlapped) were placed in sub plots and each sowing pattern represented plot as explained in Table 3, each plot was replicated three times. The preceding crop in the season of 2014-2015 was winter wheat for both fallow lands. The experiment was conducted in the second decade of November 2016 when the soil moisture was approximately $16 \%$ for both lands. The sowing by overlapping mode was carried out by adopting the mode that Parish (1999) and UMass Extension (2000) recommended by cutting each of the delivery rate and swath width to half while maintaining parallel swaths by applying: right-on-right, left-on-left overlapping with back-and-forth traffic system as shown in Figure 1.

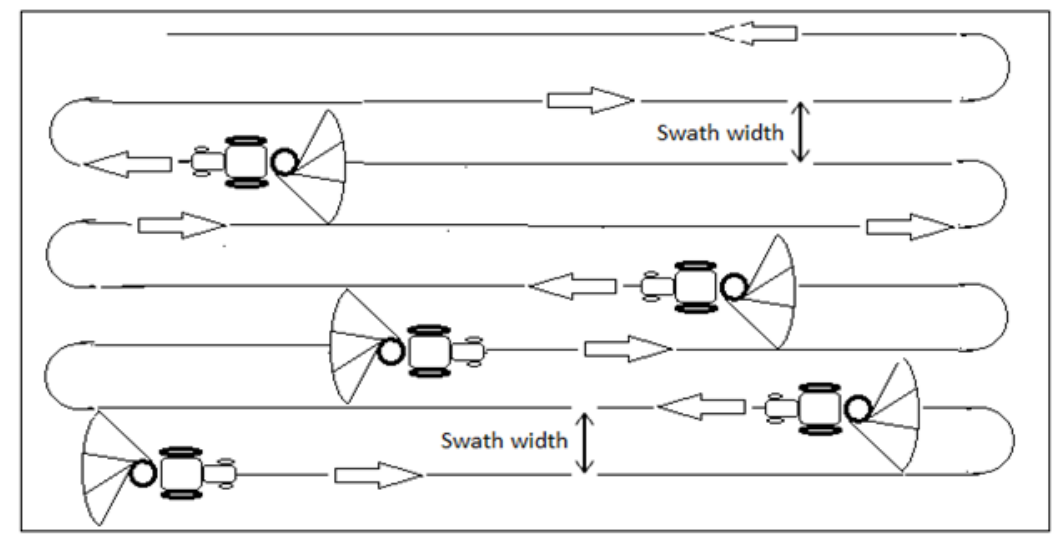

Figure 1. Half-width method and half rate application (a right-on-right) and (a left-on-left) overlap manner

\section{Calibration}

Centrifugal type broadcaster which used for this experiment had the following features: tractor mounted with P.T.O shaft driven at $540 \mathrm{rpm}$, hopper capacity of $0.8 \mathrm{~m}^{3}$, 
single spinning disc and height of the spinning disc from the ground was $1.1 \mathrm{~m}$ during operation. Table 4 shows the main features of the machines used in the present study. The seed broadcaster was calibrated for traditional sowing on rate $200 \mathrm{Kg} / \mathrm{ha}(5000000$ $\mathrm{kernel} / \mathrm{ha}$ ) a day before the study considering wind speed less than $8 \mathrm{~km} / \mathrm{h}$. According to ASAE S341.2 (1999) and as followed by Sanaeifar and Sheikhdavoodi (2012), the calibration test begun by putting twenty collecting trays $1 \times 1 \mathrm{~m}$ (each had partitions barriers) for granules in a row with equal distances to the longitudinal center line of the tractor in symmetric shape.

Table 3. Layout of the study method for the three factors (fallow lands, sowing manners and sowing patterns)

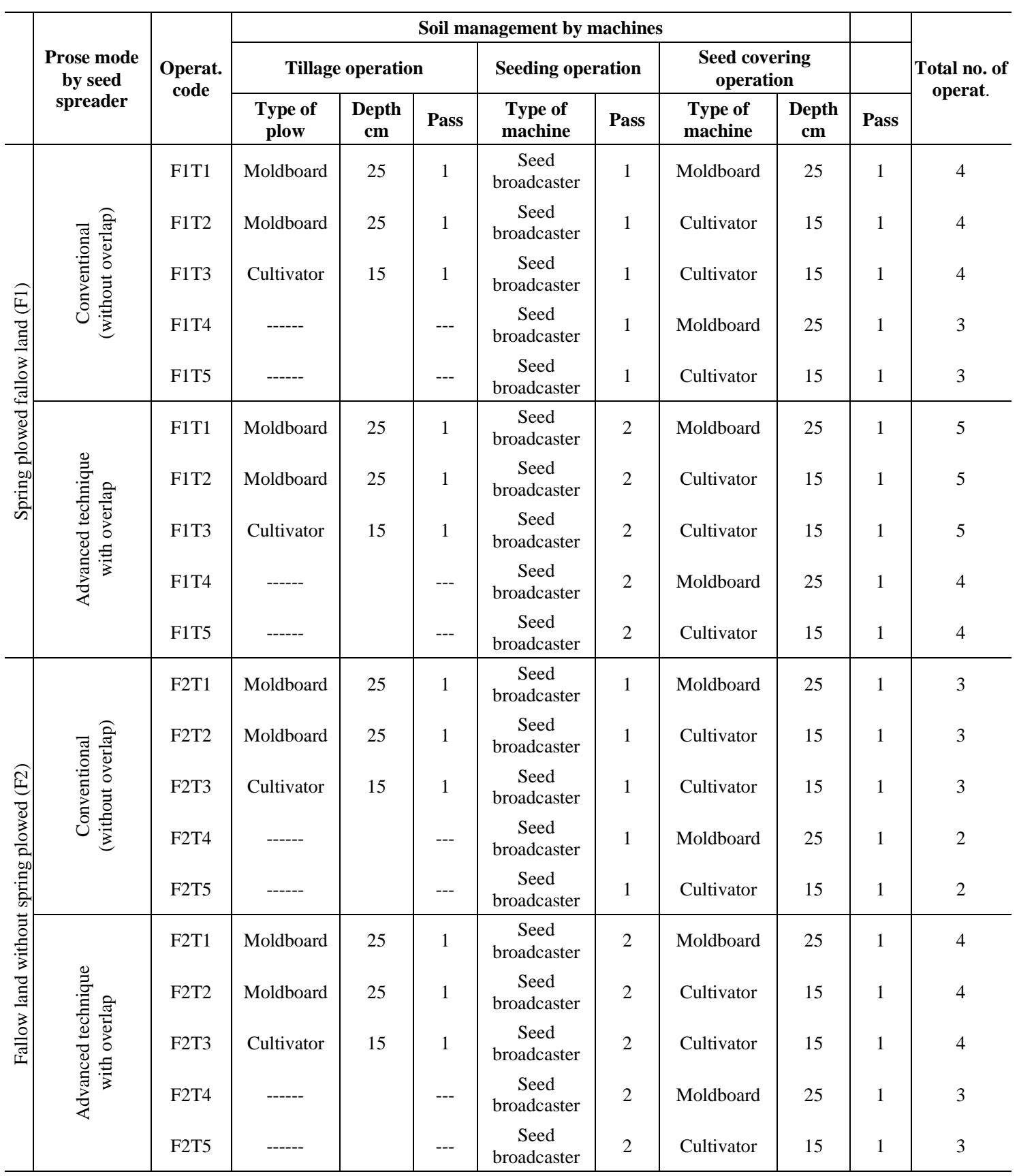


Table 4. Main features for all machines participated in the experiment

\begin{tabular}{c|c|c|c|c|c|c}
\hline Tractor/equipment & Mod. & $\begin{array}{c}\text { Weight } \\
\text { Kg }\end{array}$ & $\begin{array}{c}\text { Working } \\
\text { width } \\
\text { m }\end{array}$ & Specification & Type & $\begin{array}{c}\text { Linkage } \\
\text { with } \\
\text { tractor }\end{array}$ \\
\hline Tractor $(56 \mathrm{~kW})$ & ITM/Iran & 2812 & ---- & $\begin{array}{c}\text { 4-stroke-direct } \\
\text { injection }\end{array}$ & $4 \mathrm{WD}$ & ----- \\
\hline Mouldboard plow & Unlu/Turkey & 330 & 0.85 & 3 furrow & $\begin{array}{c}\text { General } \\
\text { purpose } \\
\text { MB }\end{array}$ & Mounted \\
\hline Cultivator & Unlu/Turkey & 240 & 2 & $\begin{array}{c}\text { 9 vertical spring } \\
\text { tines }\end{array}$ & Duck feet & Mounted \\
\hline Seed broadcaster & Solano/Spain & 68 & 16 & 500 Lt/hopper & Mono disc & Mounted \\
\hline
\end{tabular}

In accordance with Clark and Evans (1954) both the tractor and the spreader were put in a stable state and spreading begun $30 \mathrm{~m}$ before trays row and continued to $40 \mathrm{~m}$ after trays row. The calibrating tests were repeated three times at the same tractor forward speed $7.1 \mathrm{Km} / \mathrm{h}$. The collected seeds in each tray were recorded and weighed in order to determine the quantity and the uniformity of seeds distributed within the field. The collected seeds from each tray were put in a tube as represented in Figure 2. This calibration result is consistent with which confirmed by UMass Extension (2011) that, in centrifugal type broadcasters, material distributed in a fan like pattern that the intensive rates applied to the center of the spreader path while the application rates reduce to left and right of center and seems like a bell shape curve with distance of the scattered.

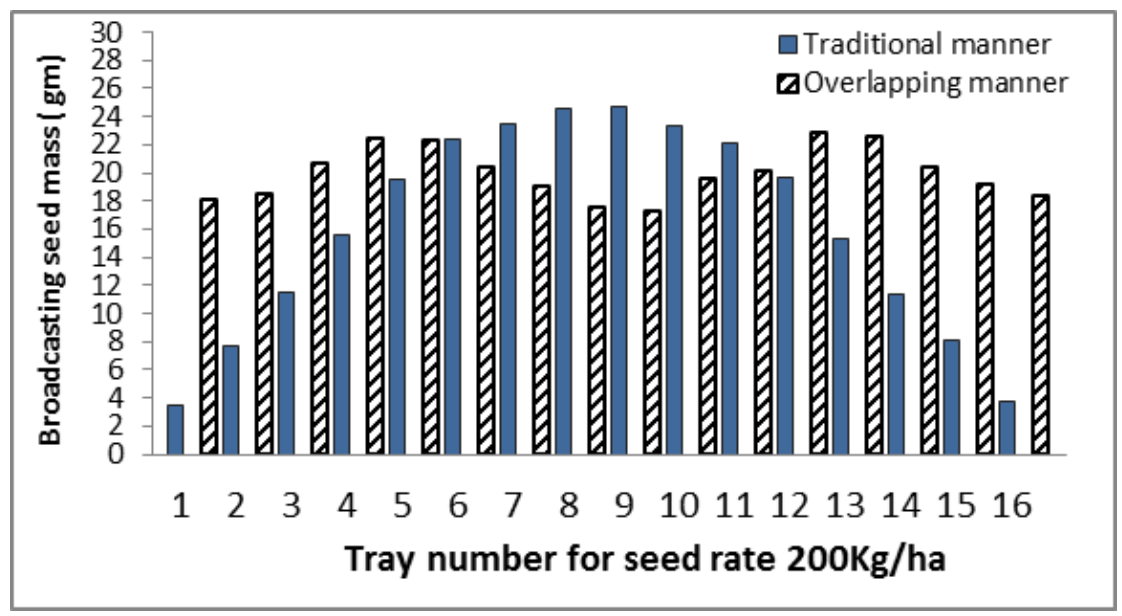

Figure 2. Pattern of seed amounts distribution in each tray after broadcaster calibration on the seed rate of $200 \mathrm{Kg} / \mathrm{ha}$

To apply the advanced technique half-width method and half rate application for the seed broadcaster as overlap sowing mode in this study, another calibration was conducted in the same manner as the previously applied method that followed for sowing rate $(200 \mathrm{Kg} / \mathrm{ha})$ but this time for the rate of $100 \mathrm{Kg} / \mathrm{ha}(2500000 \mathrm{kernal} / \mathrm{ha})$. This calibration started by the layout of 16 trays (the working width for the seed broadcaster as shown in Fig. 2) on a line perpendicular to the direction of tractor travel. 
After achieving the correct amount of seeds per hectare, the "progressive" application method conducted in alternate directions, back and forth, as mentioned before and as illustrated in Figure 1. This method was replicated several times. The results were very satisfactory in terms of the homogenous distribution of seeds and quantity.

Selected forward speed for any tillage or covering operation in this experiment was $7.1 \mathrm{Km} / \mathrm{h}$. The recorded data when the fallow land was plowed in spring by moaldboard were: the drawbar force was $11.526 \mathrm{KN}$ on $25 \mathrm{~cm}$ depth at a forward speed of $7.05 \mathrm{Km} / \mathrm{h}$ at $15 \%$ soil moisture. These values have been used and added to the relevant equations to measure the studied parameters. Necessary information for all machinery contributed in the study had given in Table 4 and Figure 3. The averages resulted from ANOVA analyses were compared by using Duncan's test.

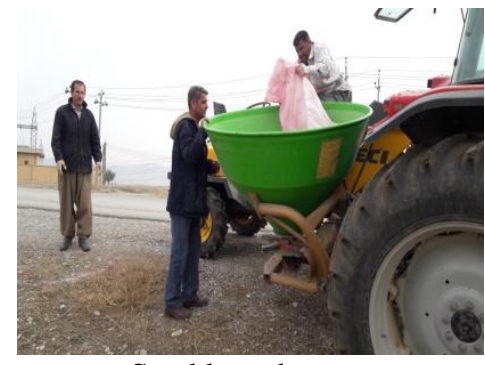

Seed broadcaster

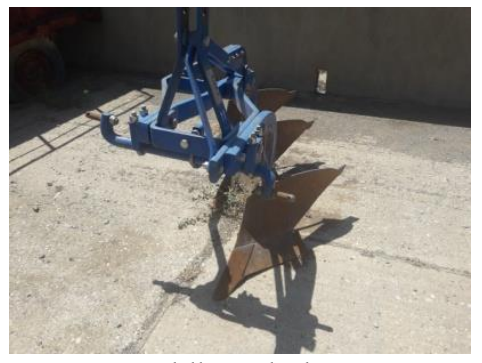

Moldboard plow

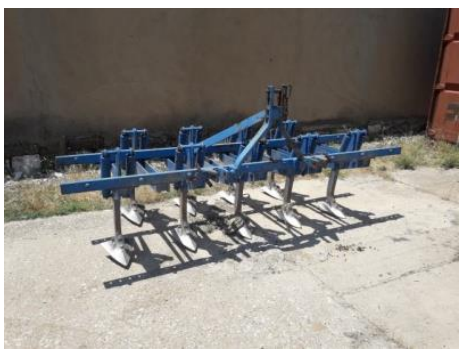

Field cultivator

Figure 3. Machines used in the study

\section{Studied indicators}

Since the machines used in this research include a heterogeneous working width, the calculation of the studied indicators was carried out on $1 \mathrm{~m}$ of machine width so as to avoid bias in favour of a specific treatment and to show the results more clearly and accurately. After measuring the results for each operation within each sowing pattern the total was calculated and adopted.

\section{The coefficient of variance (C.V)}

The percentage of mean value is the standard deviation in the form of a relative scale of dispersion. The following formula was used by Laghari et al. (2014) to measure the coefficient of variance:

$$
\begin{gathered}
C V \%=\frac{100 \times S d}{\overline{\mathrm{x}}} \\
s d=\sqrt{\frac{1}{n} \sum_{i=1}^{n}(x i-\bar{x})^{2}}
\end{gathered}
$$

where:

$\mathrm{CV}=$ coefficient of variation

$\mathrm{Sd}=$ standard deviation

$\mathrm{Xi}=$ value of an individual observation

$\overline{\mathrm{x}}=$ mean value of all observations 


\section{Total fuel consumption (L/ha). $m^{-1}$}

The fuel consumption was measured according to the standard method followed by observing the fuel needed for traveling $40 \mathrm{~m}$ long distance for completing each sowing pattern using a graduated cylinder which was directly attached to the fuel tank as Sümer et al. (2010) suggested.

\section{Total draft force $(\mathrm{KN} / \mathrm{m})$}

Total draft force was measured by using mechanical dynamometer Dillon type $(10000 \mathrm{Kg})$ for each plot.

Total power bar losses due to slippage $(\mathrm{KW} / \mathrm{m})$

It was found as the same equation followed by (Abdullah and Ghazwan, 2014).

$$
P F T(K W)=\frac{(F T \times(V T-V P) \div 3.6)}{W}
$$

where:

PFT: drawbar power lost by slippage $(\mathrm{KW} / \mathrm{m})$

VT: theoretical speed $(\mathrm{Km} / \mathrm{h})$.

Working time $(\mathrm{H} / \mathrm{Ha}) / \mathrm{m}$

It is measured as mentioned by Moitzi (2013), Firas et al. (2016) and ASABE Standards (2016) by using the following formula:

$$
\begin{gathered}
W T=\frac{1}{\mathrm{C}_{\text {theo }}} \\
\mathrm{C}_{\text {theo }}=\frac{W \times V_{\text {avg }} \times 0.1}{\mathrm{~m}}
\end{gathered}
$$

where:

WT: time required for completing any Mechanical operation $(\mathrm{H} / \mathrm{Ha}) / \mathrm{m}$

$\mathrm{C}_{\text {theo }}$ : field capacity $(\mathrm{Ha} / \mathrm{h})$

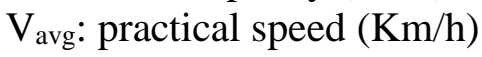

\section{Energy utilization efficiency $(\eta)\left(\mathrm{m}^{3} / \mathrm{Mj}\right)$}

Measured by the equation that McKyes (1985), Muhsin (2017) and Abdullah and Ghazwan (2014) followed:

$$
\begin{aligned}
& S R=\frac{F}{\mathrm{~A}} \\
& A=\frac{B p}{\mathrm{Dp}}
\end{aligned}
$$


where:

$\eta$ : energy efficiency $\left(\mathrm{M}^{3} / \mathrm{Mj}\right)$

$S R$ : the amount of force used by the shears on the unit area

$F$ : force

A: area

Bp: working width

Dp: working Depth

m: unit of length $(\mathrm{m})$

Wheat yield $(\mathrm{Kg} / \mathrm{Ha})$

For each plot, the yield was harvested by using thresher.

Total cost for each sowing pattern (T.C)

The total cost of any agricultural pattern was calculated separately on costs associated only with mechanical repair and maintenance, as well as fuel, lubricants and labour wages.

\section{Results}

\section{The coefficient of variance (C.V):}

Based on Table 5, the calculated result of the coefficient of variance (C.V) of seeding by traditional distribution was very high $48.4 \%$, indicating that homogeneity of distribution was very bad compared to the intertwined mode of grain distribution which gave $9.2 \%$ of variance, because, the lower the coefficient of variation, the better the distribution.

Table 5. The coefficient of variance (C.V) for spreading uniformity for the samples of seeds collected for each traditional and overlapping prose

\begin{tabular}{|c|c|c|c|c|c|c|c|c|c|c|c|c|c|c|c|c|c|}
\hline \multirow{3}{*}{ 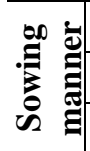 } & \multicolumn{16}{|c|}{ Collecting trays number (working width of the spreader) } & \multirow{3}{*}{$\begin{array}{c}\text { C.V } \\
\%\end{array}$} \\
\hline & \multicolumn{8}{|c|}{ Right side scattering } & \multicolumn{8}{|c|}{\begin{tabular}{|l|} 
Left side scattering \\
\end{tabular}} & \\
\hline & 1 & 2 & 3 & 4 & 5 & 6 & 7 & 8 & 9 & & & 12 & 13 & 14 & 15 & 16 & \\
\hline $\mathrm{CM}$ & 4.1 & 9.1 & 13.2 & 20.3 & 24.2 & 27.6 & 29.8 & 31.3 & 31.9 & 29.5 & 27.9 & 24.6 & 20.7 & 12.9 & 9.4 & 4.5 & 48.4 \\
\hline $\mathrm{OM}$ & 18.1 & 18.6 & 20.7 & 22.5 & 22.4 & 20.5 & 19.1 & 17.6 & 17.4 & 19.7 & 20.2 & 22.9 & 20.7 & 20.5 & 19.2 & 18.4 & 9.2 \\
\hline
\end{tabular}

CM- conventional mode, OM- overlapping mode

\section{Effect of fallow land condition}

As seen in Table 6, the fallow land condition clearly affected all studied parameters. The best averages were resulted by conducting mechanical operations on spring-plowed fallow land by: $23.80(\mathrm{~L} / \mathrm{ha}) / \mathrm{m}, 11.22 \mathrm{kN} / \mathrm{m}, 2.72 \mathrm{~kW} / \mathrm{m}$ and $5.29(\mathrm{Hr} / \mathrm{ha}) / \mathrm{m}$ for total fuel consumption, total draft need, power loss due to slippage and total time required respectively. These results differ from non-plowed land at spring with an increase of: $51.9 \%, 28.7 \%, 47.1 \%$ and $26.9 \%$ respectively. On the other hand, the fallow land that was non-plowed at spring, gave the highest averages compared to that plowed type land with percentages of $31.6 \%$ and $3.2 \%$ for both total energy utilization efficiency and total wheat production, respectively. The total cost spent on sowing the plowed fallow land at 
spring was $8.56 \mathrm{USD} / \mathrm{ha}$, which exceeds the cost spent on non-plowed land at spring by $30.2 \%$.

Table 6. Effect of fallow land condition on power requirements, total yield and total cost spent

\begin{tabular}{c|c|c|c|c|c|c|c}
\hline $\begin{array}{c}\text { Fallow land } \\
\text { condition }\end{array}$ & $\begin{array}{c}\text { Tot. F.C } \\
(\mathbf{L} / \mathbf{h a} /) / \mathbf{m}\end{array}$ & $\begin{array}{c}\text { Tot. draft } \\
\mathbf{k N} / \mathbf{m}\end{array}$ & $\begin{array}{c}\text { Tot. SDHp } \\
\mathbf{k W} / \mathbf{m}\end{array}$ & $\begin{array}{c}\text { Tot. W.t } \\
(\mathbf{H r} / \mathbf{h a}) / \mathbf{m}\end{array}$ & $\begin{array}{c}\text { Tot. E.U.E } \\
\mathbf{M}^{3} / \mathbf{M J} / \mathbf{m} *\end{array}$ & $\begin{array}{c}\text { Tot. wheat } \\
\text { yield } \\
\text { Kg/ha }\end{array}$ & $\begin{array}{c}\text { Tot. cost } \\
\mathbf{U S D} / \mathbf{h a}\end{array}$ \\
\hline F1 & $49.45 \mathrm{a}$ & $21.77 \mathrm{a}$ & $5.14 \mathrm{a}$ & $7.24 \mathrm{a}$ & $89.07 \mathrm{a}$ & $2809.36 \mathrm{a}$ & 8.56 \\
F2 & $23.80 \mathrm{~b}$ & $11.22 \mathrm{~b}$ & $2.72 \mathrm{~b}$ & $5.29 \mathrm{~b}$ & $60.92 \mathrm{~b}$ & $2620.78 \mathrm{~b}$ & 5.98 \\
\hline
\end{tabular}

*Means with similar letters in each row or column are non-significant at the $5 \%$ level (Duncan's test)

\section{Effect of sowing mode}

From the results of Table 7, the sowing method had no effect on most measured characteristics except for total energy utilized efficiency. The given results from conventional sowing method were 36.47 (L/ha)/m, $16.52 \mathrm{kN} / \mathrm{m}, 3.91 \mathrm{~kW} / \mathrm{m}$, $6.26(\mathrm{Hr} / \mathrm{ha}) / \mathrm{m}, 73.72\left(\mathrm{M}^{3} / \mathrm{MJ}\right) / \mathrm{m}$ and $2721.10 \mathrm{Kg} / \mathrm{ha}$ for the parameters total fuel consumption, total draft force, total power loss due to slippage, total working time, total energy utilization efficiency and total wheat yield, respectively. As well as, the averages from applying overlapped sowing mode were 36.78 (L/ha)/m, $16.47 \mathrm{kN} / \mathrm{m}, 3.95 \mathrm{~kW} / \mathrm{m}$, $6.26(\mathrm{Hr} / \mathrm{ha}) / \mathrm{m}, 76.27\left(\mathrm{M}^{3} / \mathrm{MJ}\right) / \mathrm{m}$ and $2809.10 \mathrm{Kg} / \mathrm{ha}$ for the studied indicators, respectively.

As observed in Table 7 the reduction percent of values obtained from using conventional manner were: $0.8 \%, 1 \%$ and $0 \%$ for total fuel consumption, total power loss due to slippage and total working time. However, the value of the draft force resulted by using overlapping method decreased at a time when it was supposed to increase. The values of the averages resulted from using sowing manners are too close to each other, and the difference between them can be considered as the amount of power spent for applying the second travel of the seed spreader in overlapped method during conducting the half-swath width and half-seed application rate. It can be said, the amount of power consumed by the seed distributor is too small compared to that consumed by other machines used for tillage operation, especially, the moldboard plow. Therefore, in practice, the amount of power consumed by the seed distributor can melt between the relatively large variations in the frequency of power values consumed by tillage machines due to the difference of the two fallow land conditions. The highest proportion of energy used to complete the agricultural process is consumed by the plows (Larson and Clyma,1995).

Table 7. Effect of sowing manner on power requirements, total yield and total cost spent

\begin{tabular}{c|c|c|c|c|c|c|c}
\hline $\begin{array}{c}\text { Sowing } \\
\text { modes }\end{array}$ & $\begin{array}{c}\text { Tot. F.C } \\
(\mathbf{L} / \mathbf{h a} / \mathbf{m} / \mathbf{m}\end{array}$ & $\begin{array}{c}\text { Tot. draft } \\
\mathbf{k N / m}\end{array}$ & $\begin{array}{c}\text { Tot. SDHp } \\
\mathbf{k W / m}\end{array}$ & $\begin{array}{c}\text { Tot. W.t } \\
(\mathbf{H r} / \mathbf{h a}) / \mathbf{m}\end{array}$ & $\begin{array}{c}\text { Tot. E.U.E } \\
\left(\mathbf{M}^{\mathbf{3}} / \mathbf{M J}\right) / \mathbf{m}^{*}\end{array}$ & $\begin{array}{c}\text { Tot. wheat yield } \\
\mathbf{K g} / \mathbf{h a} *\end{array}$ & $\begin{array}{c}\text { Tot. cost } \\
\text { USD/ha }\end{array}$ \\
\hline Conventional & $36.47 \mathrm{a}$ & $16.52 \mathrm{a}$ & $3.91 \mathrm{a}$ & $6.26 \mathrm{a}$ & $73.72 \mathrm{~b}$ & $2621.08 \mathrm{a}$ & 6.70 \\
Overlapped & $36.78 \mathrm{a}$ & $16.47 \mathrm{a}$ & $3.95 \mathrm{a}$ & $6.26 \mathrm{a}$ & $76.27 \mathrm{a}$ & $2809.06 \mathrm{~b}$ & 7.84 \\
\hline
\end{tabular}

*Means with similar letters in each row or column are non-significant at the 5\% level (Duncan's test) 
The highest amount of total energy utilization efficiency was73.72 $\left(\mathrm{M}^{3} / \mathrm{MJ}\right) / \mathrm{m}$ when conventional spreading applied, with an increase of 3.3\% than in other applications. The total wheat production was $2809.06 \mathrm{Kg} / \mathrm{ha}$ when $7.84 \mathrm{USD} / \mathrm{ha}$ spent for applying overlapping mode of seed spreading with an increase of $7.17 \%$ than the yield resulted from using conventional method.

\section{Effect of sowing patterns}

The results in Table 8 illustrate the averages of parameters studied that were affected by applying different sowing patterns. The lowest amounts for total fuel consumption, total draft force used, total power loss due to slippage and total working time were found by treating T5 pattern, which gave 20.33 (L/ha)/m, $9.37 \mathrm{kN} / \mathrm{m}, 2.08 \mathrm{~kW} / \mathrm{m}$ and $5.05(\mathrm{Hr} / \mathrm{ha}) / \mathrm{m}$ respectively, with percent of $63.2 \%, 62 \%, 65.2 \%$ and $29.2 \%$ less than averages resulted from T1 treat. The draft force of Mouldboard plow was $78.6 \%$ more than the force needed to pull field cultivator. The reason of this increase is due to the variance of the resistance force of each machine during soil preparation which depends on many factors as Keller (2004) mentioned the draft requirement for each plow dependent on implement parameters; plowing depth, forward speed and soil strength.

As well as, the highest amount of total energy utilization efficiency and total wheat yield were $122.66\left(\mathrm{M}^{3} / \mathrm{MJ}\right) / \mathrm{m}$ and $2904.80 \mathrm{Kg} / \mathrm{ha}$, respectively which resulted by applying the T3 system. While, the lowest amounts were: $73.1 \%$ and $13.9 \%$ less than the averages obtained by using T4 pattern. The lowest cost noted to complete sowing operation was $5.54 \mathrm{USD} /$ ha spent on conducting T5 operation with a reduction of $38.6 \%$ than the highest cost which spent for conduct T1 treatment.

Table 8. Effect of sowing patterns on studied power indicators, total yield and total cost

\begin{tabular}{c|c|c|c|c|c|c|c}
\hline $\begin{array}{c}\text { Sowing } \\
\text { patterns }\end{array}$ & $\begin{array}{c}\text { Tot. F.C } \\
(\mathbf{L} / \mathbf{h a} /) / \mathbf{m}\end{array}$ & $\begin{array}{c}\text { Tot. Draft } \\
\mathbf{k N} / \mathbf{m}\end{array}$ & $\begin{array}{c}\text { Tot. SDHp } \\
\mathbf{k W / m}\end{array}$ & $\begin{array}{c}\text { Tot. W.t } \\
(\mathbf{H r} / \mathbf{h a}) / \mathbf{m}\end{array}$ & $\begin{array}{c}\text { Tot. E.U.E } \\
\left(\mathbf{M}^{3} / \mathbf{M J}\right) / \mathbf{m}^{*}\end{array}$ & $\begin{array}{c}\text { Total wheat } \\
\text { yield Kg/ha* }\end{array}$ & $\begin{array}{c}\text { Total cost } \\
\text { USD/ha }\end{array}$ \\
\hline $\mathrm{T} 1$ & $55.28 \mathrm{a}$ & $24.68 \mathrm{a}$ & $5.98 \mathrm{a}$ & $7.13 \mathrm{a}$ & $66.81 \mathrm{c}$ & $2706.88 \mathrm{ab}$ & 9.02 \\
$\mathrm{~T} 2$ & $43.41 \mathrm{~b}$ & $19.68 \mathrm{~b}$ & $4.79 \mathrm{~b}$ & $7.04 \mathrm{~b}$ & $98.23 \mathrm{~b}$ & $2877.95 \mathrm{a}$ & 8.17 \\
$\mathrm{~T} 3$ & $26.56 \mathrm{~d}$ & $11.52 \mathrm{~d}$ & $2.34 \mathrm{~d}$ & $6.93 \mathrm{c}$ & $122.66 \mathrm{a}$ & $2904.75 \mathrm{a}$ & 7.28 \\
$\mathrm{~T} 4$ & $37.54 \mathrm{c}$ & $17.21 \mathrm{c}$ & $4.46 \mathrm{c}$ & $5.17 \mathrm{~d}$ & $32.98 \mathrm{e}$ & $2500.68 \mathrm{~b}$ & 6.34 \\
$\mathrm{~T} 5$ & $20.33 \mathrm{e}$ & $9.37 \mathrm{e}$ & $2.08 \mathrm{e}$ & $5.05 \mathrm{e}$ & $54.30 \mathrm{~d}$ & $2585.10 \mathrm{~b}$ & 5.54 \\
\hline
\end{tabular}

*Means with similar letters in each row or column are non-significant at the 5\% level (Duncan's test)

\section{Effect of the fallow land condition and sowing modes interactive}

The data are shown in Table 9 indicate that there is a clear effect of the interaction between soil type and agricultural ethics on most of the characteristics involved. The averages produced by applying both traditional and overlapping seeding method for each of the studied parameters did not differ in either of the two fallow lands. Lower values were observed in the case of conducting conventional broadcasting on the nonspring plowed fallow land for fuel consumption, total draft, total power loss due to slippage and total working time were: $23.66(\mathrm{~L} / \mathrm{ha}) / \mathrm{m}, 11.16 \mathrm{kN} / \mathrm{m}, 2.70 \mathrm{~kW} / \mathrm{m}, 5.29$ $(\mathrm{Hr} / \mathrm{ha}) / \mathrm{m}, 59.92\left(\mathrm{M}^{3} / \mathrm{MJ}\right) / \mathrm{m}$ and $59.92\left(\mathrm{M}^{3} / \mathrm{MJ}\right) / \mathrm{m}$, respectively, with a reduction of $52.3 \%, 48.7 \%, 47.8 \%, 26.9 \%$ and $33.9 \%$ compared to the highest values resulted from overlapped spreading on spring plowed land. The increases of energy consumed are due to the fact of using extra tillage operation by moldboard at spring, The energy and draft 
used for spring tillage at fallow land were more than in the case of only autumn plowing (Raper et al., 2000).

On the other hand, the interaction of studied factors had no effect on total wheat yield; the highest yield obtained was $2943.90 \mathrm{Kg} / \mathrm{ha}$ when the modern technique of seed scattering was adopted on the spring plowed land with total cost of 9.16 USD/ha. While, the minimum yield recorded was $2674.30 \mathrm{Kg} / \mathrm{ha}$. The lowest spent cost appeared was $5.45 \mathrm{USD} / \mathrm{ha}$ when the sowing operation was done by applying a conventional mode on the non-plowed land at spring.

Table 9. Effect of fallow land condition and sowing modes on studied power indicators, total yield and total cost

\begin{tabular}{c|c|c|c|c|c|c|c|c}
\hline $\begin{array}{c}\text { Fallow } \\
\text { land } \\
\text { condition }\end{array}$ & $\begin{array}{c}\text { Sowing } \\
\text { mode }\end{array}$ & $\begin{array}{c}\text { Tot. F.C } \\
(\mathbf{L} / \mathbf{h a} /) / \mathbf{m}\end{array}$ & $\begin{array}{c}\text { Tot. } \\
\mathbf{d r a f t} \\
\mathbf{k N} / \mathbf{m}\end{array}$ & $\begin{array}{c}\text { Tot. } \\
\mathbf{S D H p} \\
\mathbf{k W / m}\end{array}$ & $\begin{array}{c}\text { Tot. W.t } \\
(\mathbf{H r} / \mathbf{h a}) / \mathbf{m}\end{array}$ & $\begin{array}{c}\text { Tot. E.U.E } \\
(\mathbf{M} / \mathbf{M J}) / \mathbf{m} *\end{array}$ & $\begin{array}{c}\text { Total wheat } \\
\text { yield } \\
\mathbf{K g} / \mathbf{h a} *\end{array}$ & $\begin{array}{c}\text { Total cost } \\
\text { USD/ha }\end{array}$ \\
\hline \multirow{2}{*}{ F1 } & Convent. & $49.28 \mathrm{a}$ & $21.77 \mathrm{a}$ & $5.12 \mathrm{a}$ & $7.24 \mathrm{a}$ & $87.52 \mathrm{a}$ & $2674.86 \mathrm{a}$ & 7.96 \\
& Overlap & $49.62 \mathrm{a}$ & $21.77 \mathrm{a}$ & $5.17 \mathrm{a}$ & $7.24 \mathrm{a}$ & $90.61 \mathrm{a}$ & $2943.86 \mathrm{a}$ & 9.16 \\
\hline \multirow{2}{*}{ F2 } & Convent. & $23.66 \mathrm{~b}$ & $11.16 \mathrm{~b}$ & $2.70 \mathrm{~b}$ & $5.29 \mathrm{~b}$ & $59.92 \mathrm{~b}$ & $2567.30 \mathrm{a}$ & 5.45 \\
& Overlap & $23.93 \mathrm{~b}$ & $11.27 \mathrm{~b}$ & $2.74 \mathrm{~b}$ & $5.29 \mathrm{~b}$ & $61.93 \mathrm{~b}$ & $2674.26 \mathrm{a}$ & 6.52 \\
\hline
\end{tabular}

\section{Effect of the interaction between fallow land condition and sowing patterns}

Based on the results seen in Table 10, the interaction between the fallow lands condition and sowing pattern significantly affected all indicators included in the study. The lowest values for total fuel consumption, total draft, total power loss due to slippage and total working time by applying T5 operation either on F1T5 or on F2T5, were: 33.01 $(\mathrm{L} / \mathrm{ha}) / \mathrm{m}, 25.72 \mathrm{kN} / \mathrm{m}, 3.49 \mathrm{~kW} / \mathrm{m}$ and 6.04 (Hr/ha)/m respectively, with: 51.5\%, 49.4\%, $50.2 \%$ and $25.4 \%$ less than the highest values obtained by applying $\mathrm{T} 1$ operation on each fallow land condition. While, the highest amount of total energy utilization efficiency was $138.74\left(\mathrm{M}^{3} / \mathrm{MJ}\right) / \mathrm{m}$ which was obtained from using F1T3 or F2T3 with an increase of approximately $67 \%$ than the amount resulted from using F1T4 or F2T4. The maximum total wheat production was $2977.82 \mathrm{Kg} /$ ha obtained when F2T3 treatment was conducted, but, the minimum yield observed was $2473.18 \mathrm{Kg} / \mathrm{ha}$ by applying F1T4 treatment. The lowest cost was $4.17 \mathrm{USD} / \mathrm{ha}$ spent to complete the sowing operation of F2T5 by $60.3 \%$ less than the highest cost spent on using F1T1 treatment.

\section{Effect of the interaction between sowing modes and sowing patterns}

Table 11 refers to the significant effect of the interaction between sowing modes and sowing patterns on studied power indicators and total yield of wheat. The lowest values noticed for fuel consumption, total draft, total power loss due to slippage and total working time when the conventional sowing operation interacted with T5 treatment were $20.15(\mathrm{~L} / \mathrm{ha}) / \mathrm{m}, 9.35 \mathrm{kN} / \mathrm{m}, 2.07 \mathrm{~kW} / \mathrm{m}$ and $5.05(\mathrm{Hr} / \mathrm{ha}) / \mathrm{m}$, respectively, the highest values were obtained by applying overlapped technique of seed spreading with T1 operation, that is $55.45(\mathrm{~L} / \mathrm{ha}) / \mathrm{m}, 24.75 \mathrm{kN} / \mathrm{m}, 5.96 \mathrm{~kW} / \mathrm{m}$ and $7.13(\mathrm{Hr} / \mathrm{ha}) / \mathrm{m}$. The highest amount for total energy utilization efficiency was $125.43\left(\mathrm{M}^{3} / \mathrm{MJ}\right) / \mathrm{m}$, observed at the interaction of overlapped sowing technique with T3 treatment by more than four times the average obtained by the interaction of $\mathrm{T} 4$ and overlapped seeding mode. 
On the other hand, the maximum wheat production was $3097.50 \mathrm{Kg} / \mathrm{ha}$, given by the interaction of T3 pattern and overlapped sowing technique. The lowest amount of wheat production was $2437.50 \mathrm{Kg} / \mathrm{ha}$ resulted from the interaction of $\mathrm{T} 4$ with conventional seeding mode. The lowest spent cost was recorded by applying T5 operation with conventional sowing method by a reduction of $39.4 \%$ than the cost spent to complete T1 treatment with conventional sowing.

Table 10. Effect of the interaction between fallow land condition and sowing patterns on studied power indicators, total yield and total cost

\begin{tabular}{c|c|c|c|c|c|c|c|c}
\hline $\begin{array}{c}\text { Fallow } \\
\text { land } \\
\text { condition }\end{array}$ & $\begin{array}{c}\text { Sowing } \\
\text { patterns }\end{array}$ & $\begin{array}{c}\text { Tot. F.C } \\
(\mathbf{L} / \mathbf{h a} / \mathbf{m} / \mathbf{m}\end{array}$ & $\begin{array}{c}\text { Tot. draft } \\
\mathbf{k N} / \mathbf{m}\end{array}$ & $\begin{array}{c}\text { Tot. } \\
\mathbf{S D H p} \\
\mathbf{k W / m}\end{array}$ & $\begin{array}{c}\text { Tot. W.t } \\
(\mathbf{H r} / \mathbf{h a}) / \mathbf{m}\end{array}$ & $\begin{array}{c}\text { Tot. E.U.E } \\
\left(\mathbf{M}^{3} / \mathbf{M J}\right) / \mathbf{m}^{*}\end{array}$ & $\begin{array}{c}\text { Total wheat } \\
\text { yield } \\
\mathbf{K g} / \mathbf{h a} *\end{array}$ & $\begin{array}{c}\text { Total } \\
\mathbf{c o s t} \\
\mathbf{U S D} / \mathbf{h a}\end{array}$ \\
\hline \multirow{5}{*}{$\mathrm{F} 1$} & $\mathrm{~T} 1$ & $68.01 \mathrm{a}$ & $50.83 \mathrm{a}$ & $7.01 \mathrm{a}$ & $8.10 \mathrm{a}$ & $79.80 \mathrm{c}$ & $2782.75 \mathrm{ab}$ & 10.51 \\
& $\mathrm{~T} 2$ & $56.59 \mathrm{~b}$ & $42.44 \mathrm{~b}$ & $5.89 \mathrm{~b}$ & $8.01 \mathrm{~b}$ & $114.58 \mathrm{~b}$ & $2991.10 \mathrm{a}$ & 9.44 \\
& $\mathrm{~T} 3$ & $39.54 \mathrm{~d}$ & $29.59 \mathrm{~d}$ & $3.69 \mathrm{~d}$ & $7.90 \mathrm{c}$ & $138.52 \mathrm{a}$ & $2996.05 \mathrm{a}$ & 8.40 \\
& $\mathrm{~T} 4$ & $50.11 \mathrm{c}$ & $38.19 \mathrm{c}$ & $5.62 \mathrm{c}$ & $6.16 \mathrm{~d}$ & $44.91 \mathrm{e}$ & $2581.65 \mathrm{ab}$ & 7.53 \\
& $\mathrm{~T} 5$ & $33.01 \mathrm{e}$ & $25.73 \mathrm{e}$ & $3.49 \mathrm{e}$ & $6.04 \mathrm{e}$ & $67.34 \mathrm{~d}$ & $2695.25 \mathrm{ab}$ & 6.91 \\
\hline \multirow{5}{*}{ F2 } & $\mathrm{T} 1$ & $68.00 \mathrm{a}$ & $50.96 \mathrm{a}$ & $6.90 \mathrm{a}$ & $8.10 \mathrm{a}$ & $79.46 \mathrm{c}$ & $2631.00 \mathrm{ab}$ & 7.53 \\
& $\mathrm{~T} 2$ & $56.59 \mathrm{~b}$ & $42.56 \mathrm{~b}$ & $5.80 \mathrm{~b}$ & $8.01 \mathrm{~b}$ & $114.81 \mathrm{~b}$ & $2764.80 \mathrm{ab}$ & 6.91 \\
& $\mathrm{~T} 3$ & $39.55 \mathrm{~d}$ & $29.70 \mathrm{~d}$ & $3.65 \mathrm{~d}$ & $7.90 \mathrm{c}$ & $138.74 \mathrm{a}$ & $2813.45 \mathrm{ab}$ & 6.16 \\
& $\mathrm{~T} 4$ & $50.10 \mathrm{c}$ & $38.20 \mathrm{c}$ & $5.60 \mathrm{c}$ & $6.16 \mathrm{~d}$ & $44.96 \mathrm{e}$ & $2419.70 \mathrm{~b}$ & 5.16 \\
& $\mathrm{~T} 5$ & $33.01 \mathrm{e}$ & $25.72 \mathrm{e}$ & $3.49 \mathrm{e}$ & $6.04 \mathrm{e}$ & $67.39 \mathrm{~d}$ & $2474.95 \mathrm{~b}$ & 4.17 \\
\hline
\end{tabular}

*Means with similar letters in each row or column are non-significant at the 5\% level (Duncan's test)

Table 11. Effect of the interaction between sowing manner and sowing patterns on studied power indicators, total yield, and total cost

\begin{tabular}{|c|c|c|c|c|c|c|c|c|}
\hline $\begin{array}{l}\text { Sowing } \\
\text { modes }\end{array}$ & $\begin{array}{c}\text { Sowing } \\
\text { patterns }\end{array}$ & $\begin{array}{l}\text { Tot. F.C } \\
(\mathbf{L} / \mathbf{h a} /) / \mathbf{m}\end{array}$ & $\begin{array}{c}\text { Tot. draft } \\
\text { kN/m }\end{array}$ & $\begin{array}{c}\text { Tot. SDHp } \\
\mathrm{kW} / \mathrm{m}\end{array}$ & $\begin{array}{c}\text { Tot. W.t } \\
(\mathbf{H r} / \mathbf{h a}) / \mathbf{m}\end{array}$ & $\begin{array}{c}\text { Tot. E.U.E } \\
\left(\mathbf{M}^{3} / \mathbf{M J}\right) / \mathbf{m} \\
*\end{array}$ & $\begin{array}{l}\text { Total wheat } \\
\text { yield } \mathrm{Kg} / \mathrm{ha} \text { * }\end{array}$ & $\begin{array}{c}\text { Total } \\
\text { cost } \\
\text { USD/ha }\end{array}$ \\
\hline \multirow{5}{*}{ Convent } & $\mathrm{T} 1$ & $55.11 \mathrm{a}$ & $24.61 \mathrm{a}$ & $6.00 \mathrm{a}$ & $7.13 \mathrm{a}$ & $66.57 \mathrm{e}$ & $2591.30 \mathrm{abc}$ & 8.31 \\
\hline & $\mathrm{T} 2$ & $43.23 \mathrm{~b}$ & $19.66 \mathrm{~b}$ & $4.74 \mathrm{~b}$ & $7.04 \mathrm{~b}$ & $94.83 \mathrm{~d}$ & $2847.50 \mathrm{abc}$ & 7.62 \\
\hline & $\mathrm{T} 3$ & $26.48 \mathrm{~d}$ & $11.53 \mathrm{~d}$ & $2.33 \mathrm{~d}$ & $6.93 \mathrm{c}$ & $119.89 \mathrm{~b}$ & $2712.00 \mathrm{abc}$ & 6.81 \\
\hline & $\mathrm{T} 4$ & $37.38 \mathrm{c}$ & $17.19 \mathrm{c}$ & $4.40 \mathrm{c}$ & $5.17 \mathrm{~d}$ & $33.01 \mathrm{~g}$ & $2437.50 \mathrm{c}$ & 5.74 \\
\hline & $\mathrm{T} 5$ & $20.15 \mathrm{e}$ & $9.35 \mathrm{e}$ & $2.07 \mathrm{e}$ & $5.05 \mathrm{e}$ & $54.31 \mathrm{f}$ & $2517.10 \mathrm{bc}$ & 5.04 \\
\hline \multirow{5}{*}{ Overlap } & $\mathrm{T} 1$ & $55.45 \mathrm{a}$ & $24.75 \mathrm{a}$ & $5.96 \mathrm{a}$ & $7.13 \mathrm{a}$ & $67.05 \mathrm{e}$ & $2822.45 \mathrm{abc}$ & 9.74 \\
\hline & $\mathrm{T} 2$ & $43.59 \mathrm{~b}$ & $19.71 \mathrm{~b}$ & $4.85 \mathrm{~b}$ & $7.04 \mathrm{~b}$ & $101.64 \mathrm{c}$ & $2908.40 \mathrm{abc}$ & 8.73 \\
\hline & $\mathrm{T} 3$ & $26.64 \mathrm{~d}$ & $11.52 \mathrm{~d}$ & $2.35 \mathrm{~d}$ & $6.93 \mathrm{c}$ & $125.43 \mathrm{a}$ & $3097.50 \mathrm{a}$ & 7.75 \\
\hline & $\mathrm{T} 4$ & $37.70 \mathrm{c}$ & $17.22 \mathrm{c}$ & $4.51 \mathrm{c}$ & $5.17 \mathrm{~d}$ & $32.95 \mathrm{~g}$ & $2563.85 \mathrm{bc}$ & 6.95 \\
\hline & $\mathrm{T} 5$ & $20.50 \mathrm{e}$ & $9.40 \mathrm{e}$ & $2.09 \mathrm{e}$ & $5.05 \mathrm{e}$ & $54.28 \mathrm{f}$ & $2653.10 \mathrm{abc}$ & 6.04 \\
\hline
\end{tabular}

\section{Effect of interaction between fallow land condition, sowing modes and sowing patterns}

The averages of most of the characteristics shown in Table 12 were significantly affected by the interaction of the studied factors, where, the highest values were 
recorded from the interaction of $\mathrm{F} 1$, overlapped spreading and $\mathrm{T} 1$ operation, that is $68.19(\mathrm{~L} / \mathrm{ha}) / \mathrm{m}, 29.64 \mathrm{kN} / \mathrm{m}, 7.02 \mathrm{~kW} / \mathrm{m}$ and $8.10(\mathrm{Hr} / \mathrm{ha}) / \mathrm{m}$ for studied power indicators: total fuel consumption, total draft, total power loss due to slippage and total working time respectively, with an increase of $89 \%, 87.6 \%, 90.6 \%$ and $49.8 \%$ compared to the lowest values obtained from F1, overlapped sowing manner and T1 operation interaction. The highest amount of total energy utilization efficiency and total wheat yield were $141.57\left(\mathrm{M}^{3} / \mathrm{MJ}\right) / \mathrm{m}$ and $3235.00 \mathrm{Kg} / \mathrm{ha}$ resulted from applying $\mathrm{F} 1$, overlapped seeding mode and the T3 interaction. While, the lowest amount for both indicators were $21.05\left(\mathrm{M}^{3} / \mathrm{MJ}\right) / \mathrm{m}$ and $2399.50 \mathrm{Kg} / \mathrm{ha}$ respectively, which were observed when F2, conventional seeding mode and the T4 interacted. The lowest total cost was spent for conducting F2, conventional seed prosing and T5 operation interaction resulted in $3.71 \mathrm{USD} / \mathrm{ha}$, which was less by $67.3 \%$ than the highest cost which spent for completing F1, overlapped spreading manner and $\mathrm{T} 1$ treatment interaction.

Table 12. Effect of interaction between fallow land condition, sowing modes and sowing patterns on studied power indicators, total yield and total cost

\begin{tabular}{|c|c|c|c|c|c|c|c|c|c|}
\hline $\begin{array}{l}\text { Fallow } \\
\text { land } \\
\text { cond. }\end{array}$ & $\begin{array}{l}\text { Sowing } \\
\text { mode }\end{array}$ & $\begin{array}{l}\text { Sowing } \\
\text { pattern }\end{array}$ & $\begin{array}{c}\text { Tot. F.C } \\
(\mathrm{L} / \mathrm{ha} /) / \mathbf{m}\end{array}$ & $\begin{array}{c}\text { Tot. draft } \\
\text { kN/m }\end{array}$ & $\begin{array}{c}\text { Tot. SDHp } \\
\text { kW/m }\end{array}$ & $\begin{array}{c}\text { Tot. W.t } \\
(\text { Hr/ha)/m }\end{array}$ & $\begin{array}{l}\text { Tot. E.U.E } \\
\left(\mathbf{M}^{3} / \mathbf{M J}\right) / \mathbf{m}^{*}\end{array}$ & $\begin{array}{c}\text { Total wheat } \\
\text { yield } \\
\text { Kg/ha* }\end{array}$ & $\begin{array}{l}\text { Total cost } \\
\text { USD/ha }\end{array}$ \\
\hline \multirow{10}{*}{$\mathrm{F} 1$} & \multirow{5}{*}{ Convent } & T1 & $67.84 \mathrm{a}$ & 29.63 a & $7.01 \mathrm{a}$ & $8.09 \mathrm{a}$ & $79.42 \mathrm{~d}$ & $2631.80 \mathrm{bc}$ & 9.68 \\
\hline & & $\mathbf{T} 2$ & $56.40 \mathrm{~b}$ & $24.75 \mathrm{~b}$ & $5.85 \mathrm{bc}$ & $8.01 \mathrm{~b}$ & $110.60 \mathrm{c}$ & $2913.50 \mathrm{abc}$ & 8.87 \\
\hline & & $\mathbf{T 3}$ & $39.38 \mathrm{e}$ & $17.03 \mathrm{e}$ & $3.68 \mathrm{fg}$ & $7.90 \mathrm{c}$ & $135.47 \mathrm{a}$ & $2757.10 \mathrm{abc}$ & 7.93 \\
\hline & & $\mathbf{T 4}$ & $49.95 \mathrm{c}$ & $22.44 \mathrm{c}$ & $5.57 \mathrm{~d}$ & $6.15 \mathrm{~d}$ & $44.96 \mathrm{~g}$ & $2475.50 \mathrm{bc}$ & 6.93 \\
\hline & & T5 & $32.82 \mathrm{f}$ & $15.00 \mathrm{f}$ & $3.48 \mathrm{gh}$ & $6.04 \mathrm{e}$ & $67.17 \mathrm{e}$ & $2596.40 \mathrm{bc}$ & 6.37 \\
\hline & \multirow{5}{*}{ Overlap } & T1 & $68.19 \mathrm{a}$ & $29.64 \mathrm{a}$ & $7.02 \mathrm{a}$ & $8.10 \mathrm{a}$ & $80.57 \mathrm{~d}$ & $2933.70 \mathrm{abc}$ & 11.34 \\
\hline & & $\mathbf{T} 2$ & $56.78 \mathrm{~b}$ & $24.75 \mathrm{~b}$ & $5.94 \mathrm{~b}$ & $8.01 \mathrm{~b}$ & $118.56 \mathrm{~b}$ & $3068.70 \mathrm{abc}$ & 10.00 \\
\hline & & T3 & $39.71 \mathrm{e}$ & $17.02 \mathrm{e}$ & $3.71 \mathrm{f}$ & $7.90 \mathrm{c}$ & $141.57 \mathrm{a}$ & $3235.00 \mathrm{ab}$ & 8.87 \\
\hline & & T4 & $50.26 \mathrm{c}$ & $22.44 \mathrm{c}$ & $5.68 \mathrm{~cd}$ & $6.16 \mathrm{~d}$ & $44.85 \mathrm{~g}$ & $2687.80 \mathrm{abc}$ & 8.13 \\
\hline & & T5 & $33.19 \mathrm{f}$ & $15.00 \mathrm{f}$ & $3.49 \mathrm{gh}$ & $6.04 \mathrm{e}$ & $67.51 \mathrm{e}$ & $2794.10 \mathrm{abc}$ & 7.45 \\
\hline \multirow{10}{*}{$\mathrm{F} 2$} & \multirow{5}{*}{ Convent } & T1 & $42.38 \mathrm{~d}$ & $19.59 \mathrm{~d}$ & $4.98 \mathrm{e}$ & $6.16 \mathrm{~d}$ & $53.72 \mathrm{f}$ & $2550.80 \mathrm{bc}$ & 6.93 \\
\hline & & $\mathbf{T} 2$ & $30.07 \mathrm{~g}$ & $14.57 \mathrm{f}$ & $3.62 \mathrm{fg}$ & $6.07 \mathrm{e}$ & $79.05 \mathrm{~d}$ & $2781.50 \mathrm{abc}$ & 6.37 \\
\hline & & T3 & $13.58 \mathrm{i}$ & $6.02 \mathrm{~h}$ & $0.99 \mathrm{j}$ & $5.96 \mathrm{f}$ & $104.31 \mathrm{c}$ & $2666.90 \mathrm{bc}$ & 5.68 \\
\hline & & T4 & $24.81 \mathrm{~h}$ & $11.94 \mathrm{~g}$ & $3.23 \mathrm{i}$ & $4.18 \mathrm{~g}$ & $21.05 \mathrm{~h}$ & $2399.50 \mathrm{c}$ & 4.55 \\
\hline & & T5 & $7.49 \mathrm{j}$ & $3.69 \mathrm{i}$ & $0.66 \mathrm{k}$ & $4.07 \mathrm{~h}$ & $41.45 \mathrm{~g}$ & $2437.80 \mathrm{c}$ & 3.71 \\
\hline & \multirow{5}{*}{ Overlap } & T1 & $42.71 \mathrm{~d}$ & $19.86 \mathrm{~d}$ & $4.90 \mathrm{e}$ & $6.16 \mathrm{~d}$ & $53.53 \mathrm{f}$ & $2711.20 \mathrm{abc}$ & 8.13 \\
\hline & & $\mathbf{T} 2$ & $30.40 \mathrm{~g}$ & $14.67 \mathrm{f}$ & $3.75 \mathrm{f}$ & $6.07 \mathrm{e}$ & $84.72 \mathrm{~d}$ & $2748.10 \mathrm{abc}$ & 7.45 \\
\hline & & T3 & $13.58 \mathrm{i}$ & $6.02 \mathrm{~h}$ & $1.00 \mathrm{j}$ & $5.96 \mathrm{f}$ & $109.29 \mathrm{c}$ & $2960.00 \mathrm{abc}$ & 6.63 \\
\hline & & $\mathbf{T 4}$ & $25.14 \mathrm{~h}$ & $12.01 \mathrm{~g}$ & $3.34 \mathrm{hi}$ & $4.19 \mathrm{~g}$ & $21.06 \mathrm{~h}$ & $2439.90 \mathrm{c}$ & 5.76 \\
\hline & & T5 & $7.82 \mathrm{j}$ & $3.80 \mathrm{i}$ & $0.69 \mathrm{k}$ & $4.06 \mathrm{~h}$ & $41.05 \mathrm{~g}$ & $2512.10 \mathrm{bc}$ & 4.63 \\
\hline
\end{tabular}

*Means with similar letters in each row or column are non-significant at the $5 \%$ level (Duncan's test)

\section{Discussion}

\section{From Table 5}

The high percentage of coefficients of variance obtained from the traditional method of grain dispersion is due to the poor distribution of grains by rotatory type spreader as referred by most relevant research (Laghari et al., 2014). The reason of the variance may be that in centrifuge type of spreader, the grain is scattered by centrifugal force 
which pushes those falling seeds out in all directions and far away from the center of the rotation, except the side behind the driver, where they fall on the ground near the distribution center which causes an increase in the number of grains compared to places far from the center. This fact is consistent with what was confirmed by Sanaeifar and Sheikhdavoodi (2012). While, the C.V values resulting from the use of the overlap method were much better, which serves as an evidence of the good distribution of seeds that affect the equal growth opportunities between plants and increase production (Herbek and Lee, 2009).

\section{Table 6}

The large difference between the results obtained from the two land types is due to the added values from plowing by $\mathrm{MB}$ at spring. These results encourage farmers to leave their fallow land in unplowed condition, to reduce input costs with less effort, they (the farmers) don't know, that spending extra few dollars (2.58 USD/ha) will generate more money by selling the difference of the yield results from the two lands types. This is confirmed by Moitzi (2013).

\section{Table 7}

Although there is no significant effect of sowing mode on the studied indicators, however, there are slight differences observed in their averages. In fact, these differences represent the value of the second traffic of the broadcaster during applying the overlapped technique of prose lines as observed in fuel consumption, power losses due to slippage and total cost of $1.14 \mathrm{USD} / \mathrm{ha}$, which led to increase the wheat production by $3.1 \%$. The increase in the yield was due to the homogenous distribution of the seeds, which has led to equal access for food sources, this is confirmed by Herbek and Lee (2009).

\section{Results presented in Table 8}

The reasons of the increases in the total amounts measured by using T1 treatment for most indicators compared to other treatments, is due to the large variation of soil resistance force towards differences of number of passes, operation depths and equipment shears as mentioned in Table 3. Therefore, farmers tend to apply a few tillage practices than conventional tillage to reduce the energy requirements associated with a low cost, as confirmed by Kumar et al. (2013).

The obtained wheat production by applying T3 pattern was more by: $11 \%, 13.9 \%$, $0.9 \%$, and $6.8 \%$ than applying $\mathrm{T} 5, \mathrm{~T} 4, \mathrm{~T} 2$ and $\mathrm{T} 1$ treatments, respectively. The reason of these variations of wheat yield is due to the suitable management of the soil which mean available seed-soil contact, which affects positively the soil physical and chemical properties in comparison to other practices, as mentioned by Strudley et al. (2008).

\section{Table 9}

As noticed from the averages, the interaction between the fallow land condition and sowing modes had a clear effect, at a time when the seeding manner had no effect on the measured characteristics, as illustrated in Tables 9 and 8 . That means the effect of the fallow land condition is much greater than that of the sowing technique. 


\section{Table 10}

Applying minimum mechanical operation on each of spring plowed fallow land and non-plowed fallow land at spring gives minimum power consumption with lower cost in comparison to applying other tillage systems, which was also pointed by Broder et al. (1984) and Çarman et al. (2013).

\section{Table 11}

The lowest power needs and cost spent can be resulted by conducting T5 treatment with conventional sowing mode. The apparent variation in each sowing pattern in term of the number of operations, operation depth and difference of machines typically used in each agricultural process are the main reasons for the large variances between averages obtained from the overlapped factors, this is what Muazu et al. (2015) pointed out.

\section{Table 12}

The lowest power measurements and total cost need to be achieved by applying the sowing practice T5 with conventional or overlapped spreading technique on the unplowed fallow land at spring compared to the highest values resulted from using T1 operation on spring plowed fallow land. The reason for these wide variations is due to the differences in a number of operations applied, machine types and tillage depths.

In the spring, plowing operation killed a high percentage of weeds and insects, made the soil softer in terms of energy consumption and a more suitable environment was created for seed growth at the fall season than in the case of unplowed fallow land. The reduced tillage (T3), leaves more coverage of plant residues than using conventional tillage (Botta et al., 2006 and Kahloon et al., 2012). Also, the application of the overlapped seeding method was appropriate in obtaining the highest wheat production, This is consistent with what Mergani (2006) has indicated. Therefore, the growers must apply reduced tillage (T3) to minimize soil stress and to increase the yield.

\section{Conclusion}

\section{The results obtained from the experiment can lead to the following conclusions}

Applying sowing patterns on unplowed fallow land at spring gives lower power requirements and costs spent on wheat production as compared to spring-plowed fallow land cultivation, except, the total yield becomes less. Adoption of the overlapped mode of seed distribution by the broadcaster is better than applying the conventional technique to obtain high wheat production, despite the increased energy consumption and the slight increase in costs.

The lowest power consumption can occur by using conventional sowing plus field cultivator for covering the distributed seeds, and the highest power needs are occurred by excessive tillage. The recommendation is to apply reduced tillage with field cultivator for both tillage and seeds covering operations which results in the highest wheat production with acceptable cost and energy consumed. The effect of the fallow land condition is much greater than that of the sowing technique factor on the studied characteristics. Reducing a number of traffic reduces power spent and total cost. 
Exploiting a spring-plowed fallow land by conventional tillage is more expensive than applying reduced tillage system on unplowed fallow land at spring.

For future experiments the followings are suggested:

1. Using other sowing patterns which include other implements for soil tilling and covering the seeds which may give good results affect the plant growth. For example, Chisel plow plus disc harrow or, rototiller plus field cultivator.

2. Comparing the performance of twin disc type seed spreader with mono disc type through the coefficient of variance measurement which is an important factor for increasing the crop production.

3. We recommend testing further experiments on the uniformity of the seeds distribution on the soil by using both seed drill and broadcaster with overlapped lines mode and comparing the results.

4. Taking into account using different speeds and heights of the rotating disc from the ground and the forward speeds of the tractor, which are important factors affecting the ratio of the uniformity of seed spreading.

5. Studying the effect of the number of machines passes on the soil compaction and its reflection on roots, seed germination, plant growth and total yield.

\section{REFERENCES}

[1] Abdullah, A. A., Ghazwan, A. D. (2014): Studying locally made Mouldboard plow shares performance and its effect on some power requirements and plowing criteria. Mesopotamia J. of Agric. 42 (1):14-20.

[2] ASABE Standard (2016): Annual International Meeting, Paper No. 162461746. ASABE, St. Joseph, MI, pp. 1-18. DOI: 10.13031/aim.20162461746.

[3] ASAE Standards (1999): S341.2. Procedure for Measuring Distribution Uniformity and Calibrating Granular Broadcast Spreaders. 46th Ed. - ASAE, St. Joseph, MI.

[4] Asheesh, M., Vikas, K., Saurabh, S., Amit, K. (2017): Performance evaluation of strip-till seed drill for wheat. - International Journal of Scientific \& Engineering Research 8(7): 2229-5518.

[5] Askari, M., Khalifahamzehghasem, S. (2013): Draft force inputs for primary and secondary tillage implements in a clay loam soil. - World Applied Sciences Journal 21(12): 1789-1794.

[6] Bai, Y., Chen, F., Li, H., Chen, H., He, J., Wang, Q., Gong, Y. (2008): Traffic and tillage effects on wheat production on the Loess Plateau of China: 2. Soil physical properties. Soil Research 46(8): 652-658.

[7] Bashir, M. A., Dawelbeit, M. I., Eltom, M. O., Tanakamaru, H. (2015): Performance of different tillage implements and their effects on sorghum and maize grown in Gezira Vertisols, Sudan. - International Journal of Scientific \& Technology Research 4(4): 237242.

[8] Botta, G. F., Jorajuria, D., Rosatto, H., Ferrero, C. (2006): Light tractor traffic frequency on soil compaction in the Rolling Pampa region of Argentina. - Soil and Tillage Research 86(1): 9-14.

[9] Brennan, E. B., Leap, J. E. (2014): A comparison of drill and broadcast methods for establishing cover crops on beds. - Hortscience 49(4): 441-447.

[10] Broder, M. W., Doran, J. W., Peterson, G. A., Fenster, C. R. (1984): Fallow tillage influence on spring populations of soil nitrifiers, denitrifiers, and available nitrogen. Soil Sci. Soc. Am. J. 48: 1060-1067. 
[11] Çarman, K., Marakoğlu, T., Gür, K. (2013): Alternative tillage and direct seeding systems on wheat production in Middle Anatolia. - 2013 International Conference on Agriculture and Biotechnology, Kuala Lumpur.

[12] Clark, P. J., Evans, F. C. (1954): Distance to nearest neighbors as a measure of spatial relationships in population. - Ecology 35(3): 445-453.

[13] Colvin, T. S., Turner, J. H. (1980): Applying Pesticides. - AAVIM, Athens, GA.

[14] Firas, S., Matthew, J., Benjamin, R., Levi, J. (2016): The performance of farm tractors as reported by CAN-BUS measures. - An ASABE Meeting Presentation, Paper Number: 162461746. DOI: 10.13031/aim.20162461746.

[15] Forristal, D., Teagasc, O. P. (2017): Precise application of fertiliser. The Irish Agriculture and Food Development Authority, FAI meeting, Technical Bulletin Series No. 3. http://www.fertilizer-assoc.ie/publications/technical-bulletins/.

[16] Greb, B. W. 1979: Reducing drought effects on croplands in the west central Great Plains. - Info. Bull. No. 420, U. S. Dept. Agric, Washington, DC.

[17] Hanna, M. (2016): Estimating the field capacity of farm machines. - Ag Decision Maker Information Files. 8. http://lib.dr.iastate.edu/pubs_agdm/8.

[18] Hassann, M. M., Khater, I. M., YŞar, B. (2009): Effect of field size on mechanical wheat seeder performance in reclaimed lands of Egypt. - Tarım Makinaları Bilimi Dergisi 5(1): 45-51.

[19] Herbek, J., Lee, C. (2009): A Comprehensive Guide to Wheat Management in Kentucky. - University of Kentucky College of Agriculture, Lexington, and Kentucky State University, Frankfort.

[20] Houk, M. J. (2009): Conservation planting methods for native and introduced species. Plant Materials Technical Note No. 14. United States Department of Agriculture Natural Resources Conservation Service. http://www.nrcs.usda. gov/ Internet /FSE_PLANTMATERIALS/publications/lapmctn9048.pdf (accessed 24 February 2014).

[21] Kahloon, M. H., Iqbal, M. F., Farooq, M., Ali, L., Fiaz, M., Ahmad, I. (2012): A comparison of conservation technologies and traditional techniques for the sowing of wheat. - J. Anim. Plant Sci. 22(3): 827-830.

[22] Keller, T. (2004): Soil compaction and soil tillage - studies in agricultural soil mechanics. - Ph. D. thesis at the Swedish University of Agric. Sciences, Uppsala.

[23] Laghari, M., Laghari, N., Shah, A. R., Chandio, F. A. (2014): Calibration and performance of tractor mounted rotary fertilizer spreader. - International Journal of Advanced Research 2(4): 839-846.

[24] Kumar, V., Saharawat, Y. S., Gathala, M. K., Jat, A. S., Singh, S. K., Chaudhary, N., Jat, M. L. (2013): Effect of different tillage and seeding methods on energy use efficiency and productivity of wheat in the Indo-Gangetic Plains. - Field Crops Research 142: 1-8.

[25] Lan, Y., Kocher, M. F., Smith, J. A. (1999): Opto-electronic sensor system for laboratory measurement of planter seed spacing with small seeds. - Journal of Agricultural Engineering Research 72(2): 119-127.

[26] Larson, D. L., Clyma, H. E. (1995): Electro-osmosis effectiveness in reducing tillage draft force and energy forces. - Transactions of ASAE 38: 1281-1288.

[27] McKyes, E. (1985): Soil Cutting and Tillage. 1st. Ed. - Elsevier, Amsterdam.

[28] Mergani, S. (2006): Evaluation of some land preparation and sowing methods for wheat production in a northern state (Dongola area) Sudan. - Thesis, Department of Agricultural Engineering, Faculty of Agriculture, University of Khartoum.

[29] Moitzi, G., Szalay, T., Schüller, M., Wagentristl, H., Refenner, K., Weingartmann, H., Liebhard, P., Boxberger, J., Gronauer, A. (2013): Effects of tillage systems and mechanization on work time, fuel and energy consumption for cereal cropping in Austria. - Agric Eng Int: CIGR Journal 15(4): 94-101.

[30] Muazu, A., Yahya, A., Ishak, W. I. W., Khairunniza-Bejo, S. (2015): Analysis of fuel consumption and carbon dioxide emission in direct seeding wetland rice cultivation 
systems in Malaysia. - Research Journal of Applied Sciences, Engineering and Technology 11(3): 281-292.

[31] Muhsin, S. J. (2017): Determination of energy requirements, plowed soil volume rate and soil pulverization ratio of chisel plow under various operating conditions. - Basrah Journal of Agricultural Sciences 30(1): 73-84.

[32] Oyewole, C. I., Magaji, M. D., Falaki, M. (2001): Effects of sowing method and rodent control on plant establishment, growth and grain yield of two varieties of wheat (Triticum aestivum L.). - J. Agric. Environ. 2(2): 233-241.

[33] Parish, L. R. (1999b): Granular Spreaders: Selection, Calibration, Testing and Use. Louisiana Agricultural Experiment Station, Louisiana State University.

[34] Parish, R. L. (1986): Evaluation of two methods of fertilizer spreader pattern correction. Transactions of the ASAE 29(2): 370-373.

[35] Raper, R. L., Reeves, D. W., Burmester, C. H., Schwab, E. B. (2000): Tillage depth, tillage timing, and cover crop effects on cotton yield, soil strength, and tillage energy requirements. - Applied Engineering in Agriculture 16(4): 379.

[36] Sanaeifar, A., Sheikhdavoodi, M. J. (2012): Evaluating of broadcasting uniformity of centrifugal and oscillating granular broadcasters. - Research Journal of Applied Sciences, Engineering and Technology 4(15): 2460-2468.

[37] Soomro, U. A., Rahman, M. U., Odhano, E. A., Gul, S., Tareen, A. Q. (2009): Effects of sowing method and seed rate on growth and yield of wheat (Triticum aestivum). - World Journal of Agricultural Sciences 5(2): 159-162.

[38] Speelman, L. (1979): Features of a Reciprocating Spout Broadcaster in the Process of Granular Fertilizer Application. - H Veenman \& Zonen, Wageningen.

[39] Strudley, M. W., Green, T. R., Ascough, J. C. (2008): Tillage effects on soil hydraulic properties in space and time. - Soil Tillage Res. 99: 4-48.

[40] Sumer, S. K., Kocabiyik, H., Say, S. M., Cicek, G. (2010): Comparisons of 540 and 540e PTO operations in tractors thr laboratory tests. - Bulgarian Journal of Agricultural Science 16(4): 526-533.

[41] Svensson, J. E. T. (1990): Pneumatic Fertilizer Spreaders. A Review of the Literature. Technical Report. Dept. of Energy and Technology, Uppsala.

[42] UMass Extension (2011): Rotary Spreader Calibration Procedures. - Center for Agriculture, United States Department of Agriculture, Washington.

[43] Wuest, S., Albrecht, B. S. L., Skirvin, K. W. (1999): Vapor transport vs. seed-soil contact in wheat germination. - Agronomy Journal 91: 783-787.

[44] Zengin, M., Ocakoğlu, F. (2013): Effects of different tillage and fallow methods on Wheat yield and soil quality. - Romanian Agricultural Research 30: 191-198.

[45] Zewdu, A. D. (2008): Simulation of Tef seed broadcasting. - Agricultural Engineering International: CIGR Journal 10: 1-14. 